\title{
ELEKTRONCSÖVES ÉS FÉLVEZETŐS FESZÜLTSÉGSTABILIZÁLT ERŐSÍTŐ ÁRAMKÖRÖK KIVITELEZÉSE
}

\section{DESIGN OF ELECTRON TUBE AND SEMICONDUCTOR- BASED AND VOLTAGE STABILISED AMPLIFIER CIRCUITS}

\author{
Hrámcov István, ${ }^{1}$ Erdei Timotei István, ${ }^{2}$ Décsei Roland, ${ }^{3}$ Husi Géza ${ }^{4}$ \\ Debreceni Egyetem, Müszaki Kar, Debrecen, Magyarország \\ ${ }^{1}$ hristvan99@gmail.com \\ ${ }^{2}$ timoteierdei@eng.unideb.hu \\ ${ }^{3}$ roland.decsei@gmail.com \\ ${ }^{4}$ husigeza@eng.unideb.hu
}

\begin{abstract}
In this project, an electron tube circuit consisting of a voltage stabiliser, pre-amplifier, and final stage amplifier circuit was designed. One of the main aims was to reuse as many components and materials as possible, thereby decreasing the project's ecological footprint. The result is a hybrid electron tube amplifier. The function of the circuits was subsequently measured and analysed using various tests.
\end{abstract}

Keywords: electron tube, transformer, voltage stabilizer, amplifier, circuit, PL82, integrated circuit.

\section{Összefoglalás}

A projekt megvalósítása során egy elektroncsöves áramkörön alapuló feszültségstabilizáló, illetve erősítő áramkör került megalkotásra. Az eszköz elkészítésénél az egyik fő kritérium az alkatrész és a nyersanyag újrahasznosítása volt. Ezeket a még használható alkatrészeket tönkrement elektronikai eszközökből használtuk fel, ezzel is csökkentve a projekt költségeit és az ökológiai lábnyomot. A projekt megvalósításának eredményeként egy hibrid elektroncsöves erősítő került megtervezésre és megépítésre. Az áramkörök müködését ezt követően vizsgáltuk mérések és tesztek elvégzésével.

Kulcsszavak: elektroncső, transzformátor, feszültségstabilizátor, erősítő, áramkör, PL82, integrált áramkör.

\section{Bevezető}

$\mathrm{Az}$ elektroncsövek használata visszaszorult a XX. század 80-as éveinek elejére, sok területen a mai napig elengedhetetlenek ezen komponensek. Elektroncsöveket olyan helyen alkalmazunk, ahol magasfeszültséget, nagy áramfelvételt vagy akár kilowattos erősítést kívánunk elérni. Ezek az igények, habár a modern félvezetős technológiákkal kivitelezhetők, azok fenntartási költségei egekbe szökően magasak. Hőtermelésük pedig komplex és drága hűtőberendezéseket kíván. Az ipar mel-

lett az elektroncsövek a háztartásokban is megtalálhatóak. Legismertebb talán az elektroncsöves erősítő. Mely ismét térhódítást nyert az úgynevezett „csöves hangzás” miatt [1]. mikrohullámú sütők szintén nagy teljesítményü elektroncsővel, a magnetronnal generálják a mikrohullámokat. $\mathrm{Az}$ elektroncsövek rendelkeznek hátrányokkal, azokat kompenzálni tudjuk félvezetőkkel, így egy hibrid áramkört létrehozva, mely mind az elektroncsöves, mind a félvezetős technológiák előnyeit kihasználja. 


\section{Hibrid erősítő áramkör}

A hibrid erősítő elkészítése során nagyrészt újrahasznosított alkatrészek kerültek alkalmazásra. A váz, az elektroncsövek, a végfok részei és sok más alkatrész mind elektromos hulladékból kimentett komponensek voltak. Ennek nagy jelentősége van abban, hogy környezetünk szenynyezését csökkentsük, hogy az elkészítéshez szükséges költségeket is alacsonyan tartsuk. A projekt egyik célja, hogy ezzel kapcsolatban is támpontot szolgáltatunk.

\subsection{Előerősítő}

Az előerősítő (1. ábra) E83F-típusú pentódákat használ SE (single ended) A-osztályú üzemmódban. Az E83F képes $1 \mathrm{~W}$ [2] RMS teljesítményre $10 \%$ torzítás mellett, ami előerősítésnél bár nem szükséges, ez is jelzi az elektroncső rugalmasságát. A maximális anódteljesítmény 2,1 W [3]. Az előerősítők esetében triódákat alkalmaztunk, mivel a pentódák nagyobb zajszintet visznek a jelbe [4].

A jel egy 470-560 k $\Omega$-os logaritmikus potméteren keresztül eljut az első fontos elágazásba. Itt két ellenállás, R7 és R6, található.

Az R7 ellenállás az úgynevezett rácsszivárogtató ellenállás. Feladata, mint nevéből adódik, a jelnek a földre szivárogtatása. Ez az ellenállás állítja be az erősítő érzékenységét. Értéke pár száz k $\Omega$-tól egészen $1 \mathrm{M} \Omega$-ig terjedhet.

Az R6 ellenállás a rácsmegállító ellenállás. Erre azért van szükség, mivel magas frekvenciák kerülhetnek az elektroncsőbe. Ennek elkerülése végett az alul áteresztő szűrő elvágja a $20 \mathrm{kHz}$ feletti frekvenciákat. Az elektroncső munkapontbeállítását az R4 ellenállás végzi 180 ohmos értéken. Ez az ellenállás határozza meg az elektroncső üresjárati üzemét, mivel „A” osztályban működik. A

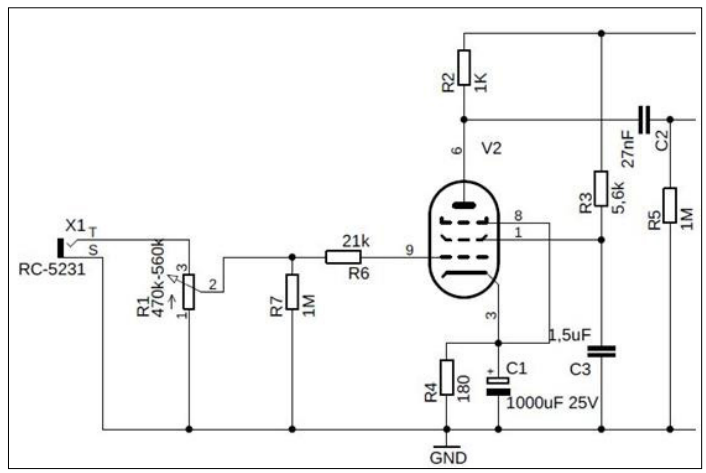

1. ábra. Az előerősítő kapcsolásirajza (részlet)
C1-kondenzátorral növelhető a cső érzékenysége (gain). Értéke $33 \mu \mathrm{F}$-tól akár $1000 \mu \mathrm{F}$-ig terjedhet.

\section{Tervezési szempontok}

Annak érdekében, hogy az elektroncsöves áramkörök vizsgálatát el tudjuk végezni, egy olyan áramkört kellett terveznünk, mely kielégíti a mérési feltételeket. Az áramkörök optimalizált alapáramkörökből lettek megtervezve annak érdekében, hogy optimálisan működjenek.

\section{A feszültségstabilizált erősítő felépí- tése}

Az eszköz dobozaként egy tönkrement mérőműszer dobozát választottuk. Mivel a műszer elektroncsöves volt, ezért a benne lévő transzformátor ideális volt számunkra. Ezenkívül elég helyet tudott biztosítani az áramkörök, illetve audis-transzformátorok számára.

Az erősítő (2. ábra) alkalmaz félvezető diódákat, melyek kis helyfoglalásuk és nagyobb hatásfokuk miatt lettek alkalmazva. BY238-típusú diódából 4 darab a nagyfeszültség egyenirányítását végzi, illetve egy helyet kapott a feszültségstabilizátor-áramkörben mint feszültségvisszafolyás-meggátló dióda. A KBL06-típusú egyenirányító híd a végfokot látja el egyenárammal. 1N4003-típusú diódák látják el a fütőszálakat egyenárammal. Az eszköz 3 fő részből épül fel: tápegység, előerősítő, végfok. A tápegység (3. ábra) transzformátort használ, melynek több kimenete van, illetve változtatható a bemeneti feszültség 110-127 és 220 V üzemre. A tápegység magában foglal egy feszültségstabilizátort, mely az előerősítő érzékeny áramkörét látja el terheléstől és bemeneti feszültségtől függetlenül 188 V-os feszültséggel. Ez a feszültség bizonyult optimálisnak az előerősítő és fázisfordító csövek számára, ezek ugyanis

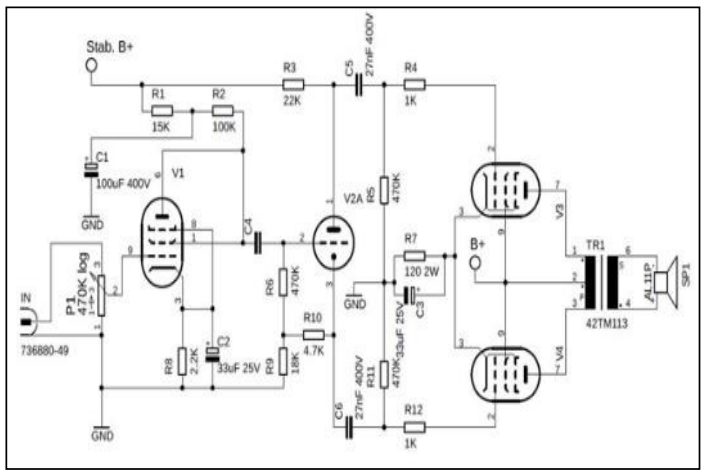

2. ábra. Az erösítő kapcsolásirajza (részlet) 


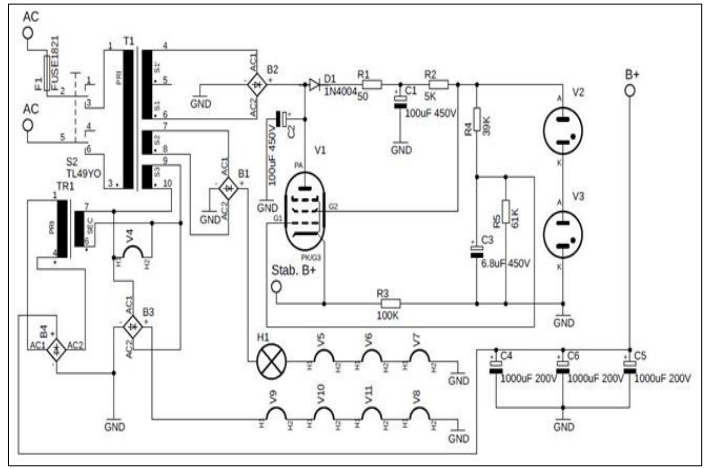

3. ábra. Tápegység

150-200 V [5, 6] üzemi feszültségen működhetnek károsodás nélkül a stabil tápegység mellett. A végfok egy egyszerü kapcsolást alkalmaz. A transzformátor 10V-os szekunder kimenetére egy másik transzformátor szekunder tekercsét kötöttük, az így kapott feszültség a második transzformátor primer tekercselésén $180 \mathrm{~V}$ AC lett. Egyenirányítás után és terhelés alatt a tápellátás $120 \mathrm{~V}$ DC lett, ez tökéletesen megfelel a PL82-típusú elektroncsöveknek. (A gyártó által ajánlott érték 170V [7].) Ez az áramkör nem igényel stabil bemenetet kapcsolásából adódóan.

\subsection{Feszültségstabilizátor működése}

A feszültségstabilizátor-áramkör stabil feszültséget szolgáltat függetlenül a terheléstől és a hálózati feszültség ingadozásától. Ez az áramkör 3 elektroncsövet használ: egy sugárpentódát és két feszültségreferencia-csövet. A 85AT2-típusú referenciacsövek egyenként $85 \mathrm{~V}$ feszültséget adnak referenciaként [8], sorosan kötve 170V. A $170 \mathrm{~V}$ mindaddig jelen lesz, amíg a feszültség nem esik a referenciacsövek nyitófeszültsége alá. Ha a terhelés hatására vagy a hálózati ingadozás hatására a feszültség eltér a referenciától, a sugárpentóda jobban kinyit, ezzel visszahozva a kívánt feszültség értékét a kimeneten [9]. Az áramkör a projekt esetében 188 V DC feszültséget ad ki.

\subsection{Az erősítő müködése}

Az erősítő három főbb részből épül fel: előerősítő, fázisfordító áramkör, push-pull konfigurációjú végfok. A jel az előerősítőbe fut be, ahol EF86-típusú pentódát alkalmaztunk trióda módban. Ha trióda módban üzemeltetjük az elektroncsövet, a zajszint jelentősen lecsökken, így megfelelővé válva alacsony jelszinteknél [5]. A jel ezek után a következő fokozat felé megy, a fázisfordító áramkörhöz. Mivel az elektroncsövek fordított polaritásban nem tudnak működni, egy fázisfordító áramkörre van szükségünk, hogy a push-pull konfigurációba elrendezett végokcsövek negatív amplitúdóért felelős ága működni tudjon. Ezt a funkciót egy PCC88-típusú elektroncső látja el. Ez egy dupla trióda [6]. A trióda anódja a pushpull pozitív ágának a vezérlőrácsát vezérli, míg a trióda katódja a negatív ág vezérlőrácsát. Ezzel a megoldással a végfok képes negatív amplitúdójú hullámot létrehozni. Mivel az elektroncsövek nagy feszültségen és alacsony áramerősségen üzemelnek, a hangszórót, mely magas áramerősségigényü alacsony feszültségen, nem lehet direktben vezérelni. Ennek megoldására audio-transzformátort kell alkalmazni.

\section{A kapcsolás megvalósítása}

Az áramkört Autodesk EAGLE-ben terveztük [10]. A tápegység és az erősítő áramkör kapcsolási rajza külön került elkészítésre az átláthatóság érdekében. A 4. ábrán látható a tápegység, mely magában foglalja a feszültségstabilizátort és a fütések számára fenntartott áramköröket is.

A fütéseket sorosan kapcsoltuk. Ennek biztonsági és tervezési okai vannak. Mivel a transzformá-
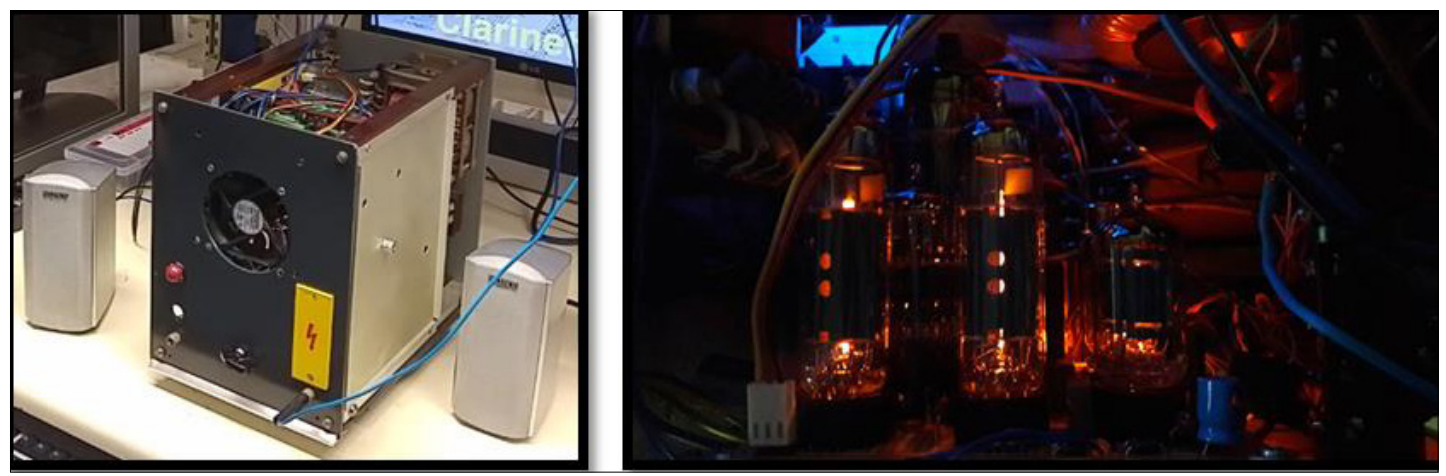

4. ábra. Az elkészült erősítő 
tort gyárilag soros fütésfüzérre tervezték, ezért a magas feszültséget soros kapcsolással elosztva megkaphatjuk a kívánt feszültséget.

A sugárpentóda, mivel $25 \mathrm{~V}$ [11] fütőfeszültséget igényel, ezért azt direktben lehet vezérelni a transzformátor fütésre kivezetett tekercséről. A 4 darab PL82-típusú pentóda a következőképpen bekötve: 2 elektroncső sorosan, majd ezzel a kapcsolással párhuzamosan a másik két elektroncső. Ezek az egyenirányítás utáni 30V-ról így megfelelően képesek üzemelni. Az előerősítő áramkörben található kettő darab EF86-, illetve PCC88-típusú csövek fütése 6,3 [5] és 7 [6] voltot igényelnek, azonban a 30 V-os feszültség miatt az áramkörhöz kellett adni sorosan egy $6.3 \mathrm{~V}$ izzót, mely a megfelelő feszültségre hozza a fütőszálakra eső feszültséget.

Az elektroncsövek erősítőknél nem igényelnek komplex áramköröket, ugyanis a tranzisztorokkal ellentétben lineárisan üzemelnek.

\section{Mérési eredmények}

\subsection{Az erősítő müködése}

Az elkészült erősítő áramkör $3 \mathrm{~W}$ teljesítményre képes, csatornánként $4 \Omega$-os terhelés mellett. $\mathrm{Az}$ erősítő áramkörök frekvencia-visszaadását speciális mérőfunkcióval rendelkező, Rhode\& Schwarz RTB2004-típusú digitális oszcilloszkóppal végeztem. A mérési tartomány $20 \mathrm{~Hz}$-től 20 kHz-i terjedt 2 Vp-p (peak to peak) jelfeszültség mellett. A beépített függvénygenerátort használtam ezen frekvenciák generálására.
A mérés előkészítéséhez egy 1 kHz frekvenciájú 2 Vp-p szinusz jelet tápláltam az előerősítő-bemenetre. Ekkor a végfok kimenetét figyelve, addig emeltem a hangerőt, míg $1 \mathrm{~W}$ teljesítményt kaptam. A teszt $20 \mathrm{~Hz}-$ ről logaritmikusan emelkedő frekvenciákkal halad $20 \mathrm{kHz}$-ig. Ideális esetben egy lineáris Bode-diagramot kapunk, azonban az erősítőben több olyan komponens is megtalálható, amely befolyásolja a görbe formáját. Többek között a jel irányába lévő kondenzátorok.

A diagramon (5. ábra) narancssárga színnel látható a gain, míg narancssárga kékkel a fázis. Megfigyelhetjük, hogy a frekvencia-visszaadás relatíve egyenes. Letörést tapasztalhatunk $40 \mathrm{~Hz}$ környékén, ami teljes mértékben elfogadható és normálisnak tekinthető. $10 \mathrm{kHz}$ felett szintén letörést tapasztalunk. Ennek oka az integrált áramkör korlátozottsága. Magas frekvenciákon nem képes megfelelő teljesítményt nyújtani torzítás nélkül. Ezért az IC kiegészítő áramköreivel korlátozni kellett a frekvencia-tartomány felső szegmensét $10 \mathrm{kHz}$ felett. Ez a lépés szükséges ennél az IC-családnál.

A jobb csatorna diagramja nagyon kis eltérést mutat a balhoz képest. Egy kisebb lefelé görbülés figyelhető meg $1 \mathrm{kHz}$ és $6 \mathrm{kHz}$ között. Ennek oka lehet a kondenzátorok és ellenállások tűrési értékével bevezetett értékkülönbség. Ennek ellenére ez a görbület emberi fül számára nem észrevehető a hangképben, és mivel nagyon hasonlóak a Bode-diagramok, ezért a sztereóhangkép kialakul a hallgató számára.

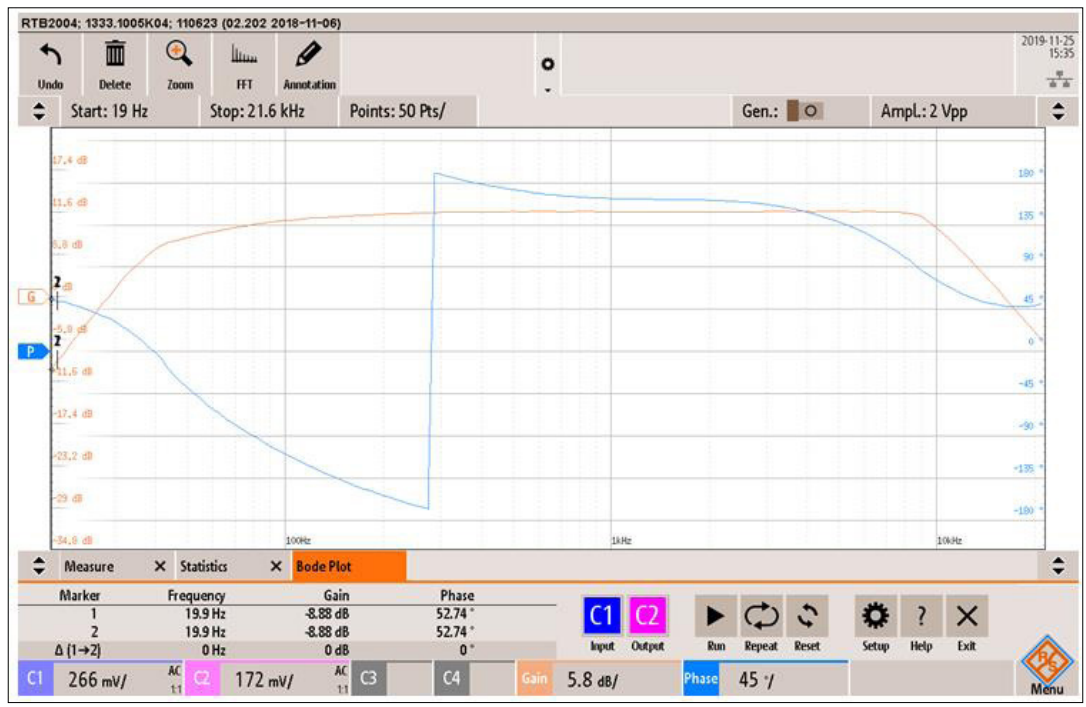

5. ábra. A bal csatorna Bode-diagramja 


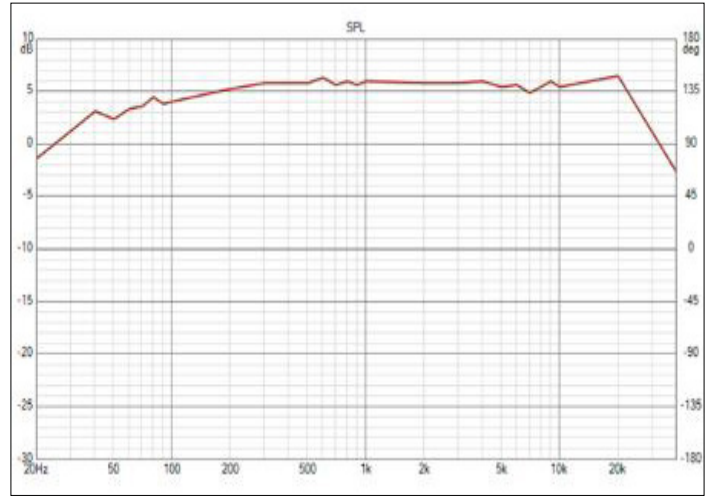

6. ábra. Bal csatorna frekvencia visszaadása hibás transzformátorral

\subsection{Elektroncsöves erősítő}

Az elektroncsövek erősítési mértékét az (1) képlet segítségével tudjuk kiszámolni:

$$
\text { Erősítés }=\frac{\mu * R(L)}{R(L)+r(p)}
$$

ahol $\mu$ az elektroncső erősítési tényezője, $\mathrm{R}(\mathrm{L}) \mathrm{a}$ terhelési ellenállás ohmban megadva, r(p) anódellenállás $\Omega$-ban megadva [12].

Az erősítő áramkör frekvencia-visszaadó képességét függvénygenerátorral (Metex MXG-9802A), digitális oszcilloszkóppal (Hantek MSO5102D) és multiméterrel (AXIO AX-588B) határoztam meg. A mérési tartományt $20 \mathrm{~Hz}$-től $20 \mathrm{kHz}$-ig végeztem.

A kapott eredményeket a VituxCAD [13] nevü szoftver segítségével grafikon formájában tüntettem fel csatornánként. (6. ábra)

Mivel ez az erősítő nem audio-transzformátort, hanem hálózati transzformátort használ a kimeneten, ezért észrevehető a frekvencia-visszaadás nonlinearitása. Ez egyszerüen abból adódik, hogy a hálózati transzformátor nem hangfrekvenciákra van méretezve.

A jobb csatorna hasonlóan teljesített, mint a bal csatorna. A sztereókép kialakul a hallgató számára, mivel a két csatorna azonos hangerővel és frekvencia-visszaadással rendelkezik.

\section{7. Összegzés, fejlesztési lehetőségek}

Az elektroncsöves és hibrid feszültségszabályozó és erősítő áramkör megépítésre került. Ezen az áramkörön méréseket végeztünk, az stabil működésre nézve. Továbbá ezen áramkörök modern felhasználási lehetőségére világítottak rá a félvezetős eszközök mellett. A projekt jövőbeli továbbfejlesztési potenciált tartalmaz magában. A transzformátoros fütőáramkör lecserélhető hatékonyabb kapcsolóüzemű tápegységre. Az audio-transzformátorok cseréjével javítható a frekvencia-visszaadás linearitása.

\section{Köszönetnyilvánítás}

Szeretném megköszönni Husi Géza tanár úrnak, hogy elvállalta a konzulensi szerepet, szakmai tudásával segített. A projekt a Debreceni Egyetem Müszaki Karán a Cyber-Physical \& Intelligent Robot Systems laborjában készült. A kutatást a Debreceni Egyetem, Informatikai Tudományok Doktori Iskola támogatta.

\section{Szakirodalmi hivatkozások}

[1] History of the Audio Amplifier, [Online]. https://sciencing.com/varactor-diode-5124911. html [Hozzáférés dátuma: 2019-11-26].

[2] E83F Datasheet, [Online]. https://frank.pocnet.net/sheets/009/e/E83F.pdf [Hozzáférés dátuma: 2019-11-26].

[3] М. Рашковский, Б. Пилипенко, В. Цирулников, Ф. Хмельницкий, Электричество в быту, Odessza, 1973

[4] TBA 790 Datasheet, [Online]. https://www.radiomuseum.org/tubes/tube_ tba790.html [Hozzáférés Dátuma: 2019-11-26].

[5] EF86 Datasheet, [Online]. https://frank.pocnet.net/sheets/010/e/EF86.pdf [Hozzáférés fátuma: 2019-11-26].

[6] PCC88 Datasheet, [Online]. https://frank.pocnet.net/sheets/010/p/PCC88.pdf [Hozzáférés dátuma: 2019-11-26].

[7] PL82 Datasheet, [Online]. https://frank.pocnet.net/sheets/030/p/PL82.pdf [Hozzáférés dátuma: 2019-11-26].

[8] 85A2T Datasheet, [Online]. https://frank.pocnet.net/sheets/190/8/85A2.pdf [Hozzáférés dátuma: 2019-11-26].

[9] Steve Bench: Tube Based Voltage Regulators. USA, 2000.

[10] T. I. Erdei, Zs. Molnár, N. C. Obinna, G. Husi: Cyber physical systems in mechatronic research centre. MATEC Web Conf. Volume 126, 2017.

[11] PL36 Datasheet, [Online]. https://frank.pocnet.net/sheets/010/p/PL36.pdf [Hozzáférés dátuma: 2019-11-26].

[12] EZ80 Datasheet, [Online]. https://frank.pocnet.net/sheets/010/e/EZ80.pdf [Hozzáférés dátuma: 2019-11-26].

[13] VituxCAD, [Online]. https://kimmosaunisto.net/Software/Software. html [Hozzáférés dátuma: 2019-11-26]. 